\title{
Body Weight Determination and Histological Examination of Livers in Normal Rats Administered with Tamsulosin
}

\author{
1'DIKKO, M; *2SARKINGOBIR, Y \\ ${ }^{1}$ Department of Pharmacy, Sultan Abdurrahman School of Health Technology Gwadabawa, Sokoto state, Nigeria \\ ${ }^{2}$ Department of Biology, Shehu Shagari College of Education Sokoto, Nigeria \\ *Corresponding Author Email: superoxidedismutase594@gmail.com; Tel: +234(0)8135420062
}

\begin{abstract}
The objective of this study was to investigate histopathology of livers and carry out body weight determination in normal rats administered with tamsulosin. Standard methods and procedures were used in this study. The results were revealed. Pertaining weight, at the $3^{\text {rd }}, 6^{\text {th }}$ and $8^{\text {th }}$ weeks of the study, no significant difference $(\mathrm{P}>0.05)$ in weight was found in the group of rats treated with carvedilol (positive control), tamsulosin low dose $(12 \mu \mathrm{g} / \mathrm{kg})$ and high dose tamsulosin $(40 \mu \mathrm{g} / \mathrm{kg})$ compared to normal control group, respectively. Other inter-groups comparisons were not significantly different, respectively. Pertaining liver morphology, liver sections of groups revealed no significant histological lesions compared to the normal control group at the $6^{\text {th }}$ and $8^{\text {th }}$ weeks of the study, respectively. This study revealed that the tamsulosin cause no histopathological lesion, thus the drug might be safe to the liver and its biochemical processes.
\end{abstract}

\section{DOI: $\underline{\text { https://dx.doi.org/10.4314/jasem.v24i8.5 }}$}

Copyright: Copyright (C) 2020 Dikko and Sarkingobir. This is an open access article distributed under the Creative Commons Attribution License (CCL), which permits unrestricted use, distribution, and reproduction in any medium, provided the original work is properly cited.

Dates: Received: 30 May 2020; Revised: 03 July 2020; Accepted: 05 August 2020

Keywords: Tamsulosin, Liver, histopathology, weight, Wistar rats

Benign prostatic hyperplasia (BPH) is a histological diagnosis that refers to the proliferation of smooth muscles and epithelial tissue in the prostate region (American Urological Association Education and Research, 2010; Dikko et al., 2020a). Lower Urinary tract symptoms (LUTS) include storage and/ or voiding problems that are common among aging men (AUAER, 2010). The spread of BPH and LUTS is increasing with age (Dikko et al., 2020b). It starts as early as at the fourties among men. In West Africa the prevalence is about $21 \%$ in men of under 60years, and $53 \%$ in men of 80 years (Ibrahim et al., 2016). In Nigeria, about $22.3 \%$ of the cases of BPH are reported from male patients. According to recent census, 3 million men are above 50years, hence, if the life expectency rise, the prevalence of BPH might rise as well (Udeh et al., 2016). The BPH or LUTS if left untreated, it can progress to complications of obstructive neuropathy, acute urinary retention, and recurrent urinary retention (Udeh et al., 2016). Presently, alpha-blockers are the most common chemotherapic drugs used to relieve BPH or LUTS. Tamsulosin is a categorical drug widely used in BPH or LUTS management. Whereas, it's used is reported to be very effective, there is paucity of studies revealing it effects on the liver (Ibrahim et al., 2016). Generally, in toxicological studies, relative weight change in an organ or organism is often associated with dose-related effects. An increase or decrease in weight easily depicts metabolic disturbance or hypoglycaemia induced by drug (Aghaghowa and Okolocha, 2018). The liver is the largest organ in human body.It carries out multiplicity of vital metabolic functions (Akuyam et al., 2017). It lies below the diaphragm and anterior stomach. It is involved in maintenance of glucose homeostasis, secretion of lipoproteins, excretion of bile, synthesis of albumin, synthesis of prothrombin, synthesis of fibrinogen, synthesis of binding protein. It is also active in metabolism of proteins, carbohydrates, and lipids. In catabolism, it is involved in degradation of hormones, serum proteins, drugs, chemicals and products of microbes etc (Arika et al., 2016; Ozougwa, 2017). Histologically, liver has a basic functional unit called lobule, which consists of plates of hepatocytes, portal triads, central vein, Kupffer cells, little canals and space of Disse (Ozougwa, 2017). Liver disease is echoed as the fifth most common cause of death after heart disease, stroke, chest disease and cancer (Dandare et al., 2015). The trend is never decreasing; rather it is on the increase especially because of recent rise of environmental pollution chemicals interaction with biological systems. Drugs are among the leading causes of liver diseases nowadays (Hadi and Alwan, 2012; Arika et al., 2016). Hepatic injury cause to liver is one of the leading challenges to public health and 
pharmaceutical industry as it leads to morbidity, mortality, drug restrictions, drug development termination and even post-market drug withdrawal (Arika et al., 2016).Therefore, the objective of this study was to investigate histopathology of livers and carry out body weight determination in normal rats administered with tamsulosin.

\section{MATERIALS AND METHODS}

Animals: Ethical approval was obtained from the Committee of Animal Care and Use, Usmanu Danfodiyo University, Sokoto. Seventy (70) male adult albino Wistar rats (261-294g) were purchased from the breeding units of Faculty of Veterinary Sciences of University of Ilorin, Nigeria. The rats were allowed in the animal house of the Department of Pharmacology and Therapeutics, Usmanu Danfodio University Sokoto, in plastic cages (four per cage) with bottoms (freshly spread with a wood saw to absorb urine) at room temperature with 12 hours light/12 hours dark cycle. Cages were cleaned daily and disinfected weekly with $70 \%$ alcohol. The rats were left for fourteen (14) days acclimatization. Tap water and pelletized grower feeds pellets product of (Vital feeds, a product of Grand cereals limited Jos, Nigeria) were suppliedad libitum (Dikko, 2019).

Experimental Design: Forty (40) male albino Wistar rats were selected using random number generator(computer software) and divided into four (4) groups of ten (10) rats each, namely, GROUP I, II, III and IV: Group I (Normal control): Distilled water $(5 \mathrm{ml} / \mathrm{kg}$ ); Group II (Positive control): Carvedilol $(800 \mu \mathrm{g} / \mathrm{kg})$ : Group III (Tamsulosin treated): Tamsulosin $(12 \mu \mathrm{g} / \mathrm{kg})$ : Group IV (Tamsulosin treated): Tamsulosin $(40 \mu \mathrm{g} / \mathrm{kg})$. They were left for three (3) days before the commencement of the study. All treatments (Distilled water, Carvedilol and Tamsulosin) were administered once daily through oral route using metal cannula attached to a $2 \mathrm{ml}$ syringe for the period of six (6) weeks. After the $6^{\text {th }}$ week of the study, all the treatments were withdrawn for a further 2 weeks ( $7^{\text {th }}$ and $8^{\text {th }}$ weeks). During the withdrawal period, only water and food were provided ad libitum. Weights of the rats in each group were measured at the beginning of the study and each week until the end of the study (Dikko, 2019).

Determination of body weight in normal rats administered with tamsulosin: Rat's weight was determined at baseline $\left(0^{\text {th }}\right)$ and at $3^{\text {rd }}, 6^{\text {th }}$, and $8^{\text {th }}$ completed week. A large plastic beaker was placed on the electronic weighing scale and tarred it back to 0 , and then the beaker was taken off. The rat was placed in the beaker and the beaker was placed back on the scale. The most frequently observed number was recorded as rat's weight (Dikko, 2019).

Histological (morphological) examination of kidneys and livers of normal rats during and after tamsulosin administration: At the $6^{\text {th }}$ week of the study, five (5) rats from each group were randomly selected after underwent 8 hours fasting. The selected rats were sacrificed by head concussion method and immediately their livers were removed and placed in a chilled fixative of $10 \%$ formal-saline. At the $8^{\text {th }}$ week of the study, the remaining rats in each group were sacrificed through head concussion after 8 hours fasting. Immediately, livers were removed and placed in a fixative of $10 \%$ formal-saline. In the laboratory, the tissues were dehydrated and cleared using xylene, then, embedded in paraffin, sectioned, and stained with hematoxylin and eosin and viewed under light microscope (Dikko, 2019).

\section{RESULTS AND DISCUSSION}

Determination of body weight at baseline $\left(0^{\text {th }}\right)$ and at $3^{\text {rd }}, 6^{\text {th }}$ and $8^{\text {th }}$ week of the study in normal rats administered with tamsulosin: At the $3^{\text {rd }}$ week of the study, no significant difference $(\mathrm{P}>0.05)$ in weight was noticed in the group of rats treated with carvedilol (positive control), tamsulosin low dose $(12 \mu \mathrm{g} / \mathrm{kg})$ and high dose tamsulosin $(40 \mu \mathrm{g} / \mathrm{kg})$ compared to normal control group. Other inter-groups comparisons were not significantly different $(\mathrm{P}>0.05$; Table 1$)$. At the $6^{\text {th }}$ week of the study, also no significant difference $(\mathrm{P}>0.05)$ in weight was observed in the group of rats administered with carvedilol (positive control), tamsulosin low dose $(12 \mu \mathrm{g} / \mathrm{kg})$ and high dose tamsulosin $(40 \mu \mathrm{g} / \mathrm{kg})$ compared to normal control group. Other inter-groups comparisons were not significantly different $(\mathrm{P}>0.05$; Table 1$)$. At the $8^{\text {th }}$ week of the study, weight of the group of rats treated with carvedilol (positive control) as well as groups of rats treated with either tamsulosin low dose $(12 \mu \mathrm{g} / \mathrm{kg})$ or tamsulosin high dose $(40 \mu \mathrm{g} / \mathrm{kg})$ did not revealed any significant differences compared to the normal control group. Other inter-group comparisons were not significantly different $(\mathrm{P}>0.05$; Table 1$)$.

Histopathology analysis of and livers at $6^{\text {th }}$ and $8^{\text {th }}$ weeks of the studyin rats treated with tamsulosin: Liver sections of groups showed no significant histological lesions compared to the normal control group at the $6^{\text {th }}$ week of the study (Table 2 and Plates 4- 5). At the $8^{\text {th }}$ week of the study, liver sections of all treated groups showed no significant histological lesions compared to normal control group (Table 2 and Plates 6-9). The relative weight change is useful in explaining the adverse effect triggered by a drug (Yazici-Tutunis et al., 2016). 
Table 1: Effect of tamsulosin on body weight at baseline $\left(0^{\text {th }}\right)$ and at $3^{\text {rd }}, 6^{\text {th }}$ and $8^{\text {th }}$ week of the study in normal rats administered with tamsulosin

\begin{tabular}{lllll}
\hline Week & $\begin{array}{l}\text { Normal control } \\
\text { (Distilled } \\
\text { water), } \mathbf{5 m l} / \mathbf{k g}\end{array}$ & $\begin{array}{l}\text { Positive control } \\
\text { (Carvedilol), } \\
\mathbf{8 0 0} \boldsymbol{\mu g} / \mathbf{k g}\end{array}$ & $\begin{array}{l}\text { Tamsulosin } \\
\text { treated group, } \\
\mathbf{1 2} \boldsymbol{\mu g} / \mathbf{k g}\end{array}$ & $\begin{array}{l}\text { Tamsulosin } \\
\text { treated group, } \\
\mathbf{4 0} \boldsymbol{\mu g} / \mathbf{k g}\end{array}$ \\
\hline $0^{\text {th }}$ & $290.8 \pm 3.49^{\mathrm{a}}$ & $281.2 \pm 2.84^{\mathrm{a}}$ & $283.6 \pm 1.41^{\mathrm{a}}$ & $288.6 \pm 2.14^{\mathrm{a}}$ \\
$3^{\text {rd }}$ & $296.5 \pm 3.36^{\mathrm{a}}$ & $289.0 \pm 2.12^{\mathrm{a}}$ & $287.7 \pm 1.59^{\mathrm{a}}$ & $294.1 \pm 1.94^{\mathrm{a}}$ \\
$6^{\text {th }}$ & $303.2 \pm 2.77^{\mathrm{a}}$ & $295.2 \pm 1.99^{\mathrm{a}}$ & $295.4 \pm 1.92^{\mathrm{a}}$ & $299.5 \pm 1.98^{\mathrm{b}}$ \\
$8^{\text {th }}$ & $308.5 \pm 3.88^{\mathrm{a}}$ & $304.3 \pm 3.19^{\mathrm{a}}$ & $300.0 \pm 2.27^{\mathrm{a}}$ & $303.3 \pm 3.19^{\mathrm{a}}$ \\
\hline
\end{tabular}

Results expressed as Mean (gram) \pm SEM ( $n=10)$. ANOVA was used followed by Tukey Kramer post hoc test. Groups within the same row with same superscript letters are not significantly different.

Table 2: Effects of the tamsulosinonthe liverat $6^{\text {th }}$ week of the study in rats treated with tamsulosin

\begin{tabular}{llll}
\hline Groups & Organs & Effects & Plates \\
\hline Normal control (Distilled water), $5 \mathrm{ml} / \mathrm{kg}$ & Liver & Appeared normal $(5 / 5$ & - Plate 4.2 \\
Positive control (Carvedilol) $800 \mu \mathrm{g} / \mathrm{kg}$ & Liver & Appeared normal $(5 / 5)$ & - Plate 4.5 \\
Tamsulosin treated, $12 \mu \mathrm{g} / \mathrm{kg}$ & Liver & Appeared normal $(5 / 5)$ & - Plate 4.7 \\
Tamsulosin treated, $40 \mu \mathrm{g} / \mathrm{kg}$ & Liver & Appeared normal $(5 / 5)$ & - Plate 4.9 \\
\hline \multicolumn{2}{c}{ Numbers in parenthesis indicate positive slides over total numbers of slides examined }
\end{tabular}

Table 3: Effect of tamsulosin on liverat $8^{\text {th }}$ week of study inrats treated with tamsulosin

\begin{tabular}{llll}
\hline Groups & Organs & Effects & Plates \\
\hline Normal control (Distilled water), $5 \mathrm{ml} / \mathrm{kg}$ & Liver & Appeared normal $(5 / 5)$ & - Plate 4.11 \\
Positive control(Carvedilol) $800 \mu \mathrm{g} / \mathrm{kg}$ & Liver & Appeared normal $(5 / 5)$ & - Plate 4.13 \\
Tamsulosin treated, $12 \mu \mathrm{g} / \mathrm{kg}$ & Liver & Appeared normal $(5 / 5)$ & - Plate 4.15 \\
Tamsulosin treated, $40 \mu \mathrm{g} / \mathrm{kg}$ & Liver & Appeared normal $(4 / 4)$ & - Plate 4.17 \\
\hline \multicolumn{2}{c}{ Numbers in parenthesis indicate positive slides over total number of slides examined }
\end{tabular}

One observation of the present study was the lack of negative effect of tamsulosin on rats' body weight. This was similar to the past studies which showed that alpha-1 adrenoceptors blockers have an advantageous effect on total cholesterol and triglycerides (Kabra, 2014). This observation might suggest that this drug have normal effect on leptic (a hormone that contribute hugely in weight regulation), dopamine, and serotonin (Yazici-Tutunis et al., 2016). Other researchers have proposed mechanisms via which alpha-1 adrenoceptorblockers affect cholesterol and triglyceride synthesis which include up-regulation of low-density lipoprotein receptors, leading to suppression of 3-hydroxy-3-methyl-glutarylcoenzyme A reductase (HMG) activity and consequently leading to a reduction in total cholesterol and low-density lipoprotein(Katzung, 2009). Another proposed mechanism is via blockade of alpha-1 adrenoceptors, which affect serum lipids by increasing the activity of lipoprotein lipase enzymes that determine the breakdown of very low-density lipoproteins (Enroth et al., 2018). Weight is of great concern nowadays. Overweight is associated with obesity, which is a risk factor of many deadly diseases such as diabetes, cancer, hypertension, liver disease, cardiovascular disease and cancer(Yazici-Tutunis et al., 2016). Moreover, present study revealed lack of significant histological lesions in the livers of the tamsulosin and carvedilol-administered rats, indicating that the two (2) drugs are not hepatotoxic. Previous studies echoed that, tamsulosin hardly causes symptomatic liver injury and it is similar to other alpha-1 adrenoceptors blockers in causing mild and self-limited forms of liver injury (Dikko, 2019). Liver is an organ known to participate fully in blood glucose homeostasis (Dashty, 2013) as well as in drug excretion and biotransformation (Dandare et al., 2015). Liver is considered the most important organ for animal or human growth. It is important to evaluate the state of health of liver since this organ played a role in many disease processes and health either primarily or secondarily because to any liver damage distort metabolic processes essential for health and growth (Suhair and Eman, 2009; Ozougwu, 2017).

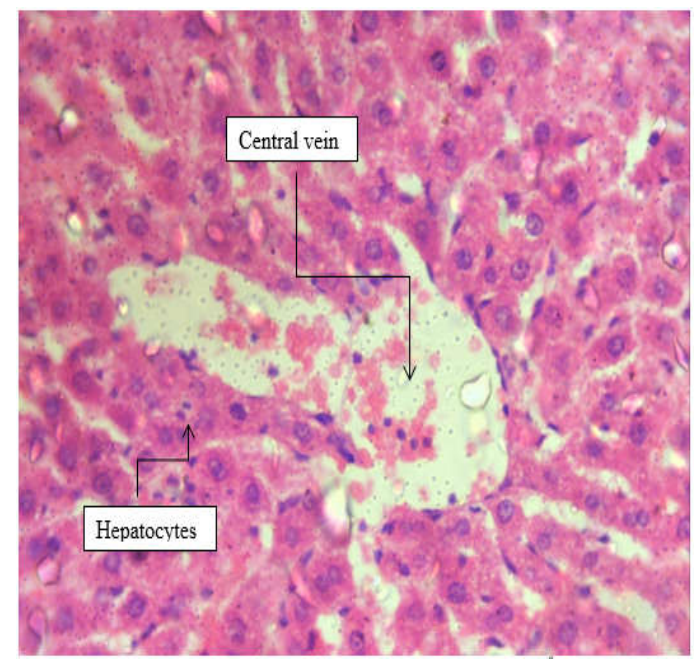

Plate 1: Photomicrograph of the liver of normal rats treated with distilled water $(5 \mathrm{ml} / \mathrm{kg})$ at $6^{\text {th }}$ week of the study showing central vein surrounded by hepatocytes having regular normal nuclei and cytoplasm. H \& E x 400 


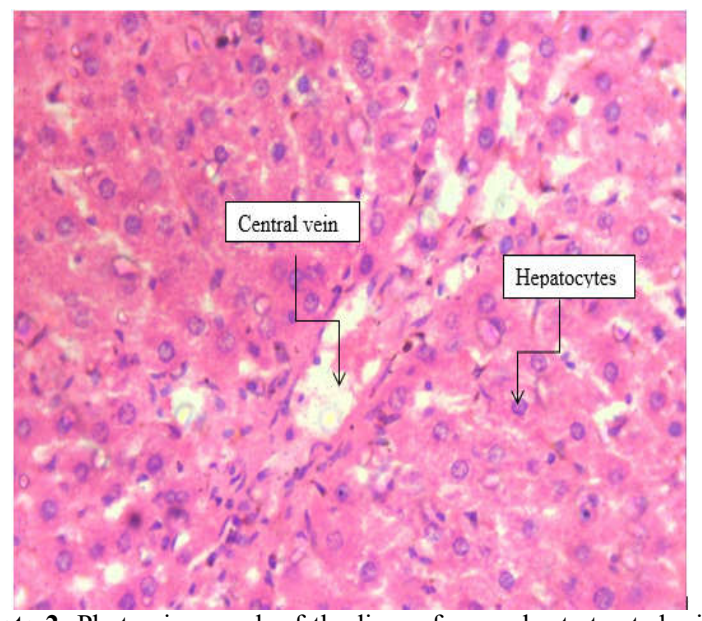

Plate 2: Photomicrograph of the liver of normal rats treated with carvedilol $(800 \mu \mathrm{g} / \mathrm{kg})$ at $6^{\text {th }}$ week of the study showing central vein surrounded by hepatocytes having regular normal nuclei and cytoplasm. H \& E x400

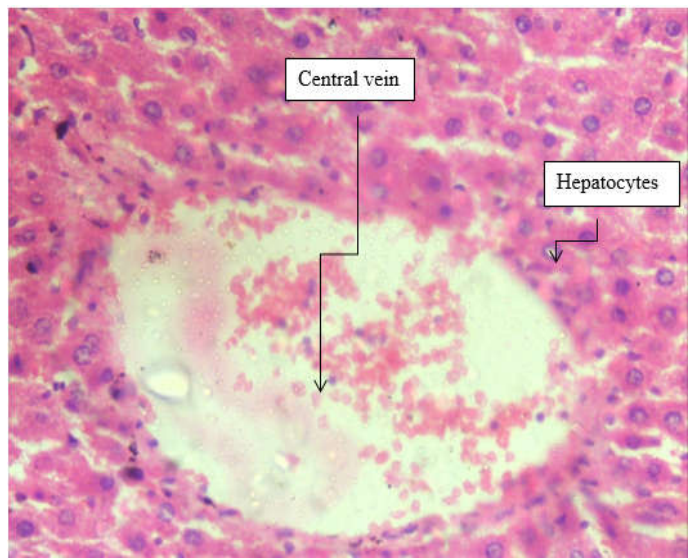

Plate 3: Photomicrograph of the liver of normal rats treated with tamsulosin $(12 \mu \mathrm{g} / \mathrm{kg})$ at $6^{\text {th }}$ week of the study showing central vein surrounded by hepatocytes having regular normal nuclei and cytoplasm. H \& E x 400

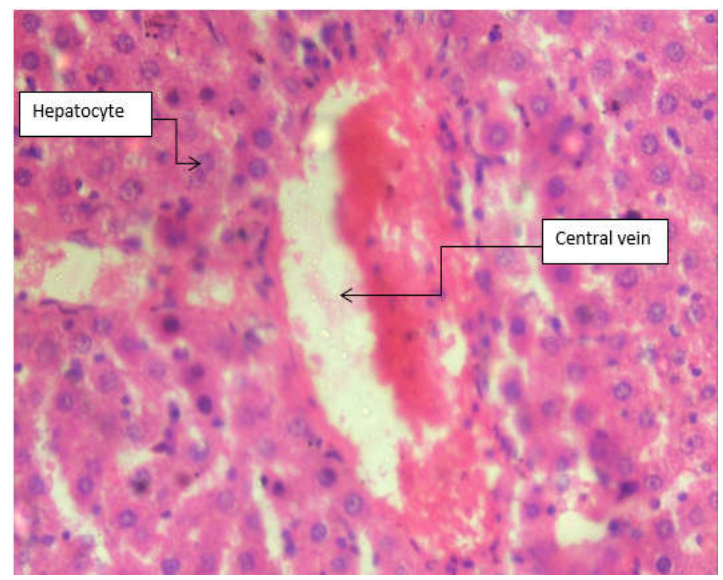

Plate 4: Photomicrograph of the liver of normal rats treated with tamsulosin $(40 \mu \mathrm{g} / \mathrm{kg})$ at $6^{\text {th }}$ week of the study showing central vein surrounded by hepatocytes having regular normal nuclei and cytoplasm. H \& E x 400

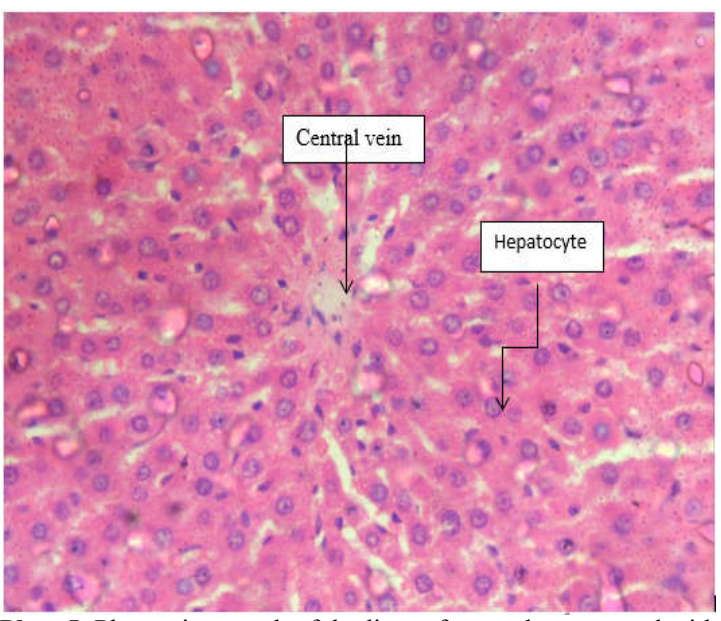

Plate 5: Photomicrograph of the liver of normal rats treated with distilled water $(5 \mathrm{ml} / \mathrm{kg})$ at $8^{\text {th }}$ week of the study showing central vein surrounded by hepatocytes having regular normal nuclei and cytoplasm. H \& E x400

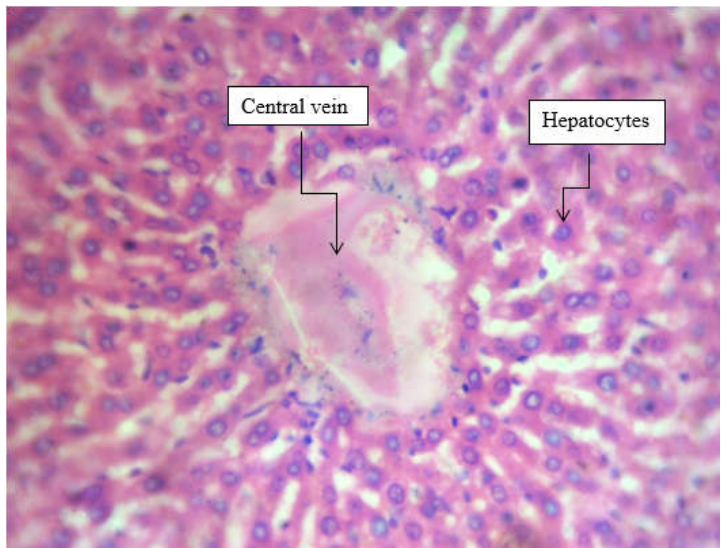

Plate 6: Photomicrograph of the liver of normal rats treated with carvedilol $(800 \mu \mathrm{g} / \mathrm{kg})$ at $8^{\text {th }}$ week of the study showing central vein surrounded by hepatocytes having regular normal nuclei and cytoplasm. H \& E x400

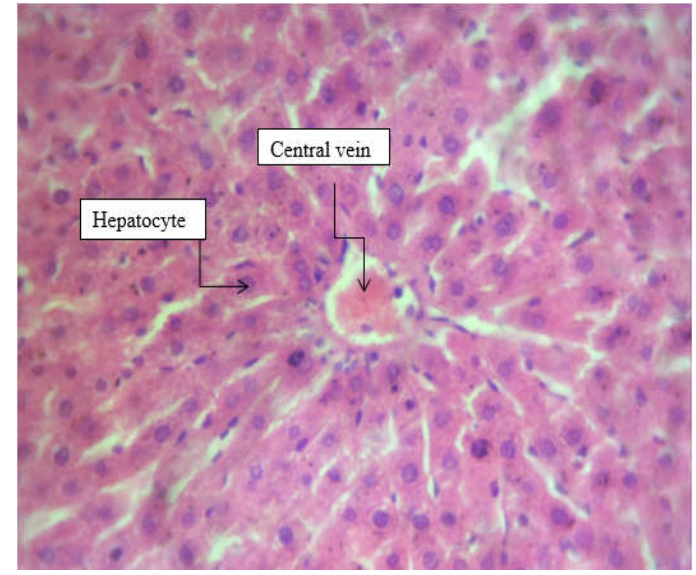

Plate 7: Photomicrograph of the liver of normal rats treated with tamsulosin $(12 \mu \mathrm{g} / \mathrm{kg})$ at $8^{\text {th }}$ week of the study showing central vein surrounded by hepatocytes having regular normal nuclei and cytoplasm. H \& E x4. 


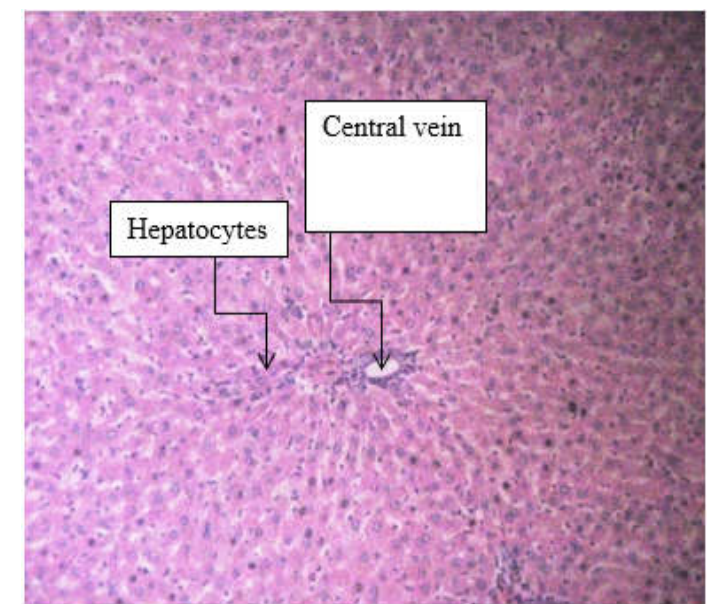

Plate 8: Photomicrograph of the liver of normal rats treated with tamsulosin $(40 \mu \mathrm{g} / \mathrm{kg})$ at $8^{\text {th }}$ week of the study showing central vein surrounded by hepatocytes having regular normal nuclei and cytoplasm. H \& E x400.

Histopathological investigations has long been recognized to examine specific organs hat are vital in physiological processes such as liver, which carry out many activities within the body such as biotransformation of drugs, chemicals and other xenobiotics. The alterations found in organs through histopathology are easier to identify, and serve as warning portend of damage to organisms health (Hadi and Alwan, 2012; Dandare et al., 2015). Exposure of liver to some chemicals or drugs leads to morphological changes and in turn affects homeostatic balance of many processes (Arika et al., 2016). Drug induced hepatic injury have become a major hurdle to pharmaceutical industry leading drug development termination, post-market withdrawal and many more (Karadeniz et al., 2008; Sharif et al., 2013; Abubakar et al., 2015; Arika et al., 2016; Odusanya et al., 2017; Enroth et al., 2018; Kaplan, 2019).

Conclusion: This study revealed that the tamsulosin cause no histopathological lesion, thus the drug might be safe to the liver and its biochemical processes. It also does not affect the body weight of the rats.

\section{REFERENCES}

Abubakar, MG, Abduljalil MM, Bola-Alaka G., Nasiru Y.I., (2015). Influence of ARVs on some biochemical changes in liver non-enzymatic markers of HIV positive patient's specialist Hospital Sokoto, Nigeria. Niger. J. Basic Appl. Sci. 23(1): 45-50.

Aghahowa, S; Okolocha, K (2018). Comparative effects of anti-malarial in Swiss albino mice after exposure to Plasmodium berghei. Ani. Mod. Exper. Medi.1:235-241.
Akuyam, SA; Abubakar, A; Lawal, N; Yusuf, R; Aminu, SM; Hassan, A; Musa, A; Bello, AK; Yahaya, IA; Okafor, PA (2017). Assessment of biochemical liver function tests in relation to age among steady state sickle cell anemia patients. Niger. J. Clin. Pract. 20: 1428-1433.

American Urological Association Education and Research (2010). American Urological Association guideline: Management of benign prostatic hyperplasia $(\mathrm{BPH})$.

Arika, WM; Nyamai, DW; Osano, KO; Ngugi, MP; Njgi, ENM (2016). Biochemical markers of invivo hepatotoxicity. J. Clini. Toxicol. 6(2): 297235.

Dandare SU., Bawa M., Wasagu IZ., Magaji UF(2015). Hepatoprotective effect of quail egg against carbon tetrachloride (CCL4) induced hepatic damage in albino rats. PHCOGJ., 7(2):102-106.

Dashty, M. (2013). A quick look at biochemistry: Carbohydrate metabolism. Clin. Biochem.46 (15): 1339-1352.Dikko M., (2019). Exploration of gross effect of tamsulosin on glucose and insulin kinetics in rats and humans. A thesis submitted to the Posgraduate School Usmanu Danfodiyo University Sokoto, Nigeria.

Dikko, M; Bello, SO; Chika, A; Mungadi, IA; Sarkingobir Y; UMAR, AI(2020a). Effect of tamsulosin use on plasma insulin status in benign prostatic hyperplasia patients in Sokoto, Nigeria. J. Appl. Sci. Environ. Manage. 24 (4) 543- 548.

Dikko, M; Bello, SO; Chika, A; Mungadi, IA; Sarkingobir, Y (2020b). Determination of Oral Glucose Tolerance (OGT) of benign prostatic hyperplasia patients treated with tamsulosin in Sokoto state, Nigeria. Niger. J. Pharma. Appli. Sci. Res. 9(2): 33-39.

Enroth, S; Maturi, V; Berggrund, M; Enroth, SB;Moustakas, A; Johansson, Å (2018). Systemic and specific effects of antihypertensive and lipidlowering medication on plasma protein biomarkers for cardiovascular diseases. Scienti. Reports. 8 (1): 5531.

Hadi, AA., Alwan, SF(2012). Histopathological changes in gills, liver, and kidney of fresh water fish , Tilapia zillii, exposed to aluminium.Intern.J.Pharm.LifeSci.,3(11):20712081. 
Ibrahim, SS; Clertus, AI; Gideon, OC; Mamzhi, RV; Kutan, DN (2016). Tamsulosin $0.4 \mathrm{mg}$ in the treatment of symptomatic BPH: Assessment of response in African mean. J. Dental. Med. Sci. 15(12): 03-07.

Kabra, N.K. (2014). Alpha blockers and metabolic syndrome. J. Associ.Physi. India 62: 13-16.

Kaplan, S.A. (2019). Re: Long-Term Dutasteride Therapy in Men with Benign Prostatic Hyperplasia Alters Glucose and Lipid Profiles and Increases Severity of Erectile Dysfunction. The J. Urol.201 (3): 416-417.

Karadeniz, A; Pişkin, İ; Eşsiz, D; Altintaş, L (2008). Relaxation Responses of Trigonal Smooth Muscle from Rabbit by Alpha1-Adrenoceptor Antagonists Alfuzosin, Doxazosin and Tamsulosin. Acta Veterina. Brunensis 77 (1): 8188.

Katzung, B.G. (2004). Drug receptors and pharmacodynamics. Basic \& clinical pharmacology, $9^{\text {th }} \quad$ ed. (McGraw-Hill Medical):17-19.

Odusanya, BO; Tijjani, KH; Jeje, EA;Ogunjini, MA;Ojewola, RW(2017). Shorterm effect of tamsulosin and finasteride monotherapy and their combination on Nigerian men with benigh prostatic hyperplasia. Niger. J. Surg. 23:5-10.
Ozougwu, J(2017). Physiology of the liver.Intern. J.Res.Pharm.Biosci.4(8): 13-24.

Pool, JL; Lenz, ML; Taylor, AA (1990). Alpha 1adrenoreceptor blockade and the molecular basis of lipid metabolism alterations. J. Human Hyper.Suppl. 3: 23-33.

Sharif, BH; Gabi, B; Yusuf, H (2013). Haematological changes induced on the selected organs of wistar rats by the extracts from herbs of ethnomedicinal application. Niger. J. Chem. Res. 18: 48-57.

Suhair IB and Eman MN (2009). Histopathological and bacteriological studies on livers affected with fasciolliasis in cattle. Egypt. J. Comp. Pathol. Clin. Pathol. 22(1): 19-45.

Udeh, EI; Ofoha, CG; Adewole, DA; Nnabugwu, II (2016). A cost effective analysis of fixed-dose combination of dustasteride and tamsulosin compared with dustasteride monotherapy for benign prostatic hyperplasia in Nigeria: A middle income perspective; using Markov model. $B M C$ Cancer, 16(405): 1-9.

Yazici-Tutunis S., Gurel-Gurevin E., Ustunova s., Demirci-Tansel C., Mericli, F (2016). Possible effects of Phillyrea latifolia on weight loss in rats fed a high-energy diet. Pharma. Biol. 54(10): 1991-1997. 